This item was submitted to Loughborough's Research Repository by the author.

Items in Figshare are protected by copyright, with all rights reserved, unless otherwise indicated.

\title{
RoMEO Studies 1: the impact of copyright ownership on academic author
} self-archiving

PLEASE CITE THE PUBLISHED VERSION

LICENCE

CC BY-NC-ND 4.0

\section{REPOSITORY RECORD}

Gadd, Elizabeth A., Steve Probets, and Charles Oppenheim. 2019. "Romeo Studies 1: The Impact of Copyright Ownership on Academic Author Self-archiving”. figshare. https://hdl.handle.net/2134/279. 
RoMEO Studies 1: The impact of copyright ownership on academic author selfarchiving

Elizabeth Gadd, Charles Oppenheim, and Steve Probets

Department of Information Science, Loughborough University, Loughborough, Leicestershire, LE11 3TU, UK.

Correspondence to Charles Oppenheim, email: C.Oppenheim@lboro.ac.uk

This article has been published in the Journal of Documentation, 59(3), 243-277

\title{
Autobiographical note
}

Charles Oppenheim is a Professor of Information Science, Dr Steve Probets a Lecturer, and Elizabeth Gadd a Research Associate, in the Department of Information Science at Loughborough University. Prof. Oppenheim is the Director of the RoMEO project, and Dr Probets the Technical Director.

\begin{abstract}
This is the first of a series of studies emanating from the UK JISC-funded RoMEO Project (Rights Metadata for Open-archiving) which investigated the IPR issues relating to academic author self-archiving of research papers. It considers the claims for copyright ownership in research papers by universities, academics, and publishers by drawing on the literature, a survey of 542 academic authors and an analysis of 80 journal publisher copyright transfer agreements. The paper concludes that selfarchiving is not best supported by copyright transfer to publishers. It recommends that universities assert their interest in copyright ownership in the long term, that academics retain rights in the short term, and that publishers consider new ways of protecting the value they add through journal publishing.
\end{abstract}

\section{Key words}

Universities; Publishers; Academics; copyright ownership; self-archiving; openaccess.

\section{$1 \quad$ Introduction}

This article is the first in a series of studies emanating from the UK JISC-funded RoMEO Project (Rights Metadata for Open-archiving) (2003). The project was tasked with considering all the intellectual property rights (IPR) issues relating to the open-archiving of research papers by UK academics. Its principal aim was to produce some rights metadata elements by which academics could describe the rights status of their 'give-away' literature, thus affording it some protection in an open-access environment. This paper considers the impact of copyright ownership on the openaccess movement.

The question of copyright ownership in research papers created by academic staff (A) in Universities $(\mathrm{U})$ and its transfer on to publishers $(\mathrm{P})$ has been the topic of much discussion in the Higher Education (HE) community for many years (Oppenheim, 1996; AAU/ARL, 1994). It has come under particular scrutiny in 'serials crisis' debates where librarians have objected to 'buying back' copyright materials (in the form of highly-priced journals) that members of their own academic community have 'given away' to publishers for free. It is perhaps not surprising, therefore, that the UA-P triangle is once again under the microscope as a potential solution to the serials 
crisis is being promoted in the academic community (Suber, 2003). That solution is the open access movement. Proponents argue that research papers currently given away to 'toll-gated' journals should instead be made openly available through free web-based access (Harnad, 2001). The movement has adopted two main strategies: i) author self-archiving through institutional or subject-based repositories (such as ArXiv (2003)), and ii) freely available electronic journals. Institutional repositories have been promoted as the fastest way to make open access a reality (Crow, 2002). However, for the institutional repository model to be a success, the current U-A-P copyright transfer chain may need revisiting.

This paper examines the attitudes of the three parties towards copyright ownership in research output by drawing on the results of investigations by RoMEO Project staff. It then considers the effect of copyright ownership on the success of the open-access initiative, and makes recommendations for a way forward.

\section{$2 \quad$ Methodology}

Three methodologies were employed. Firstly, a literature review on the various IPR relationships between universities, their academic staff, and publishers was undertaken. Secondly, academics' views on the U-A and A-P relationship were gathered from the RoMEO survey of academic authors. Thirdly, an understanding of publishers' views on the A-P relationship was gained through an analysis of a large number of journal Copyright Transfer Agreements (CTAs).

\subsection{Academic author survey}

The aims of the academic author survey were:

1) To understand academics current practices with regards to the creation of, and the copyright in, research papers;

2) To understand academics current practices and views regarding author selfarchiving;

3) To understand how academics wished to protect their own freely-available research papers on the web with a view to informing the development of some rights metadata elements for this purpose;

4) To understand how academics used other peoples' freely available research papers on the web.

An online questionnaire was designed covering the four areas above. The questionnaire was divided into three sections: A - About You, B - Your research papers, and C - How you use other peoples' research papers. Section A collected demographic information. Section B collected information on how academics wished to protect their own freely available research papers and Section $\mathrm{C}$ collected information on how academics usually used other peoples' research papers. This paper examines the results of Section A and some of Section B.

The questionnaire was piloted in late 2002, and then advertised on a number of discussion lists including:

- Emerald's Literati Club (2003) - 16,000 authors worldwide with a geographical profile similar to their subscriber base.

- September98-Forum 
- Open Archives Forum

- OAI Implementers

- University Science and Technology Librarians Group. (Members were asked to advertise the survey via their own University mailing lists. Three members from Loughborough University, University of Liverpool and Aston University notified us that they had done so but there may have been others.)

The questionnaire was also mounted on all of the ArXiv (physics subject-based eprint archive) mirror sites.

\subsection{Response rate and demographics}

Five-hundred and forty-two responses were received. As the questionnaire was online and advertised by email, it was impossible to calculate the response rate.

\subsubsection{Nationality}

Five-hundred and forty respondents indicated their nationality (or in some cases their country of residence); respondents came from 57 countries. The number of responses from each nationality group are listed in Table 1 below.

\begin{tabular}{|c|c|c|c|c|c|}
\hline Nationality & $\begin{array}{c}\text { No. } \\
\text { respondents }\end{array}$ & Nationality & $\begin{array}{c}\text { No. } \\
\text { respondents }\end{array}$ & Nationality & \begin{tabular}{|c|} 
No. \\
respondents
\end{tabular} \\
\hline UK & 176 & Denmark & 4 & Argentina & 1 \\
\hline USA & 92 & Japan & 4 & Belarus & 1 \\
\hline Australian & 24 & Malaysia & 4 & Botswana & 1 \\
\hline Canada & 20 & Mexico & 4 & Columbia & 1 \\
\hline \begin{tabular}{|l} 
Germany \\
\end{tabular} & 20 & Russia & 4 & Egypt & 1 \\
\hline \begin{tabular}{|l} 
Italy \\
\end{tabular} & 18 & Taiwan & 4 & Hungary & 1 \\
\hline Spain & 17 & Turkey & 4 & Luxembourg & 1 \\
\hline France & 13 & Belgium & 3 & Romania & 1 \\
\hline India & 13 & $\begin{array}{l}\text { Czech } \\
\text { Republic }\end{array}$ & 3 & Saudi Arabia & 1 \\
\hline Netherlands & 10 & Israel & 3 & Serbia & 1 \\
\hline \begin{tabular}{|l} 
China \\
\end{tabular} & 9 & Singapore & 3 & Slovakia & 1 \\
\hline Greece & 8 & Hong Kong & 2 & South Korea & 1 \\
\hline New Zealand & 8 & Indonesia & 2 & Sudan & 1 \\
\hline Sweden & 8 & Malta & 2 & Tanzania & 1 \\
\hline Ireland & 7 & Nigeria & 2 & Thailand & 1 \\
\hline Austria & 5 & Norway & 2 & Ukraine & 1 \\
\hline Finland & 5 & Portugal & 2 & Uzbekistan & 1 \\
\hline Poland & 5 & Scotland & 2 & & \\
\hline Brazil & 4 & South Africa & 2 & & \\
\hline Bulgaria & 4 & Algeria & 1 & & \\
\hline
\end{tabular}

Table 1 Nationality of respondents

It can be seen that by far the largest nationality group represented was the UK, with a third of respondents (176) describing themselves as such. The USA, Australia, Canada and Germany contributed the next largest tranche of respondents representing $17 \%, 4 \%, 3 \%$ and $3 \%$ of the total respectively. 


\subsubsection{Subject discipline}

Respondents were asked to name their subject discipline. All but one respondent did so. For analysis, the disciplines were broadly divided into three categories: Social Sciences and Humanities (SSH), Science, and Engineering. Figure 1 below shows the breakdown.

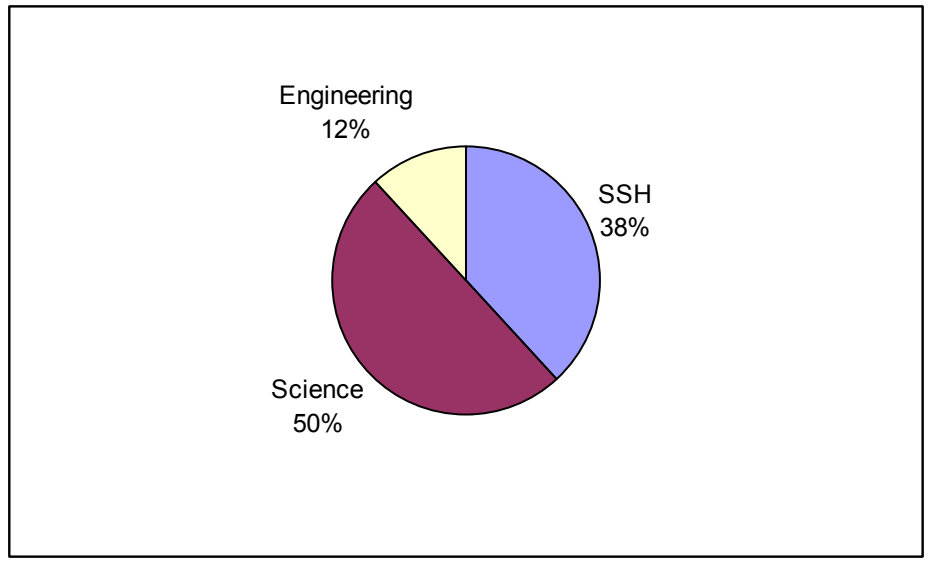

Figure 1 Broad subject disciplines of respondents

By virtue of advertising the questionnaire through a number of subject-based lists (e.g., Emerald and the ArXiv sites), certain subject disciplines appeared more frequently in the responses. These are given in Table 2 below.

\begin{tabular}{|l|c|}
\hline Subject discipline & No. respondents \\
\hline Physics & 59 \\
\hline Library \& Information Science & 59 \\
\hline Business/Management & 54 \\
\hline Maths & 30 \\
\hline Computer Science & 29 \\
\hline Marketing & 23 \\
\hline Elec/Elec Eng & 16 \\
\hline Engineering & 15 \\
\hline Economics & 14 \\
\hline Biology & 13 \\
\hline Mechanical Engineering & 13 \\
\hline
\end{tabular}

Table 2 Frequently occurring subject disciplines

The principal subject areas covered by Emerald's Journal list are: Management, Library and Information Science, and Engineering. ArXiv covers physics, mathematics and computing. These cover 6 of the 11 disciplines described above. Library and Information Science academics were also likely to be interested in the subject area and thus were more likely to respond than those from other disciplines.

\subsubsection{Length of time as academics}

Respondents were asked how long they had worked in academia. They were given four options: 5 years or less, 6-10 years, 11-15 years and More than 15 years. The responses are illustrated in Figure 2 below. 


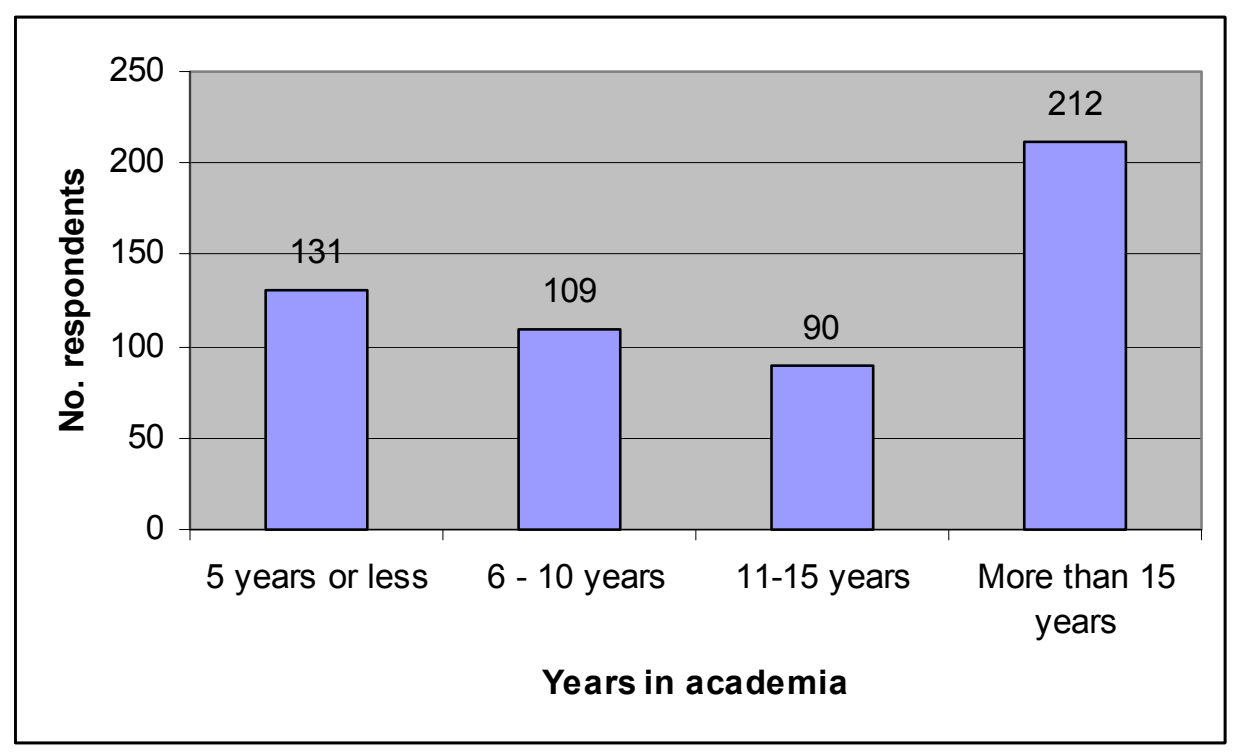

Figure 2 Length of academic service

The majority of respondents (39\%) were long-standing members of the academic community, with over 15 years service. The next largest group of respondents (24\%) were relatively new to academia with less than five years' service. Overall, there appeared to be a fairly good distribution of respondents with differing lengths of academic service.

\subsubsection{Number of papers}

Respondents were asked to indicate approximately how many research papers they had published in their careers. Five-hundred and thirty-five responded. From the 513 that gave actual figures (rather than " $>100$ " for example) the total number of research papers was calculated at 21,653 . That is an average of 42 papers per respondent. The spread of responses is given in Figure 3 below.

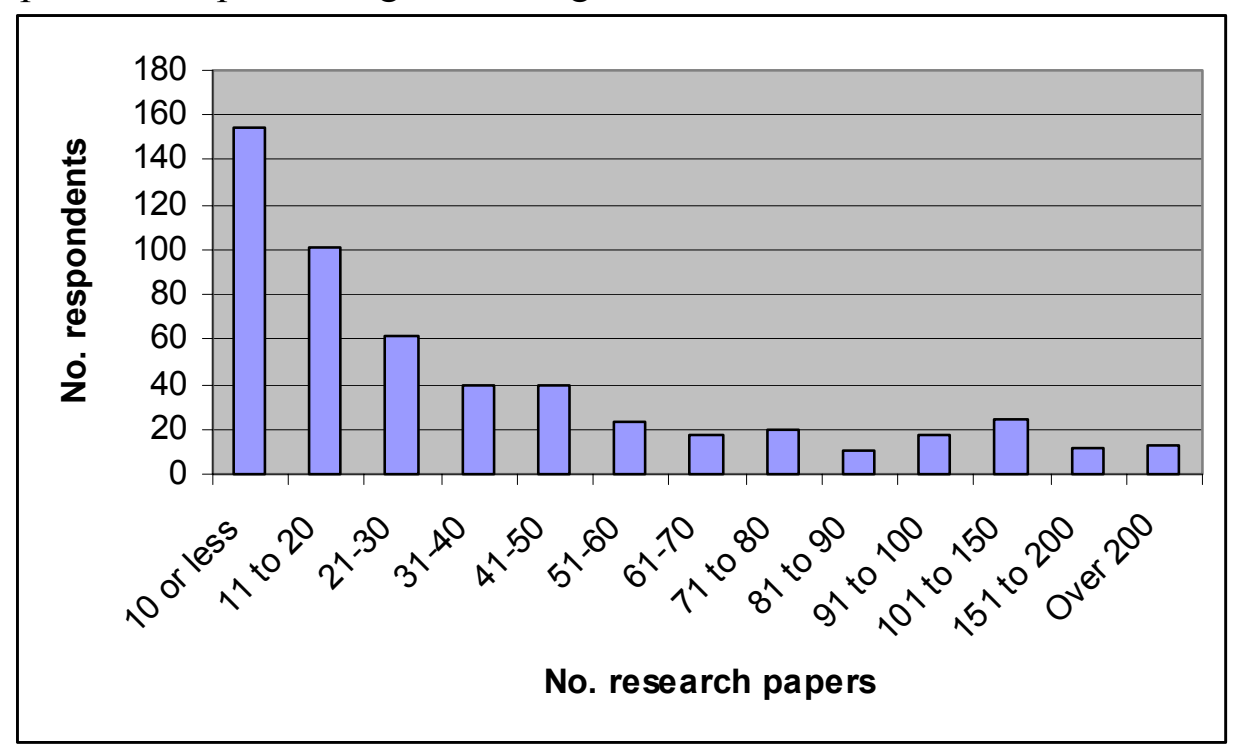

Figure 3 Research papers published by respondents during their careers

Interestingly, although the majority of respondents had been in academia over fifteen years, the largest proportion had published ten or fewer papers during their careers. However, it should be borne in mind that the number of research papers published 
will be affected by a wide range of factors, especially subject discipline. There may also have been some confusion over the term 'research paper' which was not defined in the survey.

\subsection{Publisher CTA analysis}

Two approaches were taken in order to select journal publishers for the copyright transfer agreement analysis: a targeted approach and a self-selecting approach. It was important that the research focused on publishers of high-impact, refereed academic journals as opposed to popular titles. The pressure to publish in quality journals is considerable amongst academics for reasons of promotion and tenure, and in the UK, for a good Research Assessment Exercise (RAE) rating (Jaffe, 2002). It was decided therefore, firstly, to look at the top 50 journals by impact factor in both the Science and Social Sciences ISI Journal Citation Reports editions for 2001. The publishers of those top journals were identified and added to the target list.

An approach was also made to Ulrichs Periodicals Directory who kindly supplied a list of the top 53 journal publishers by the number of academic refereed titles. The UK Office of Fair Trading (2002) had also produced a list of the top 20 STM journal publishers by the number of ISI-rated titles they owned for its report into the market for STM journals. These publishers were also added to the target list. The resulting list, after removal of duplicates (and merged publishers), amounted to 84 journal publishers. Contact details for all 84 were identified and an email advertising the project and asking for copies of copyright transfer agreements or licences was sent out to each. In addition to the targeted approach, it was decided to send out a general call for CTA's via two professional bodies for academic journal publishers: the Association of Learned and Professional Society Publishers (ALPSP, 2003) in the UK, and the Society for Scholarly Publishing (2003) in the US.

Agreements were collected between August and December 2002. After examining a small number of agreements a list of criteria was developed against which all agreements would be analysed. The analysis fell into eleven categories. This paper focuses on the results from categories a, b, c, d, and h:

a) What rights are assigned? (the assignment statement itself)

b) Whether the publisher provides a licence option

c) Whether the publisher provides an option for employers that retain copyright, or for government-owned works.

d) Whether the publisher specified why they require copyright assignment

e) What rights are kept? (e.g. moral rights)

f) When are they assigned? (pre- or post- refereeing)

g) What the author warrants

h) Exceptions to those rights (e.g. what the author is allowed to do with their own work)

i) Exception conditions

j) Self- archiving conditions (conditions that specifically apply to self-archiving)

k) What publisher will do in return for copyright assignment

Where a publisher had different agreements for different journals, an agreement from a high-impact journal was taken where possible for analysis. If a publisher had a general agreement for a group of journals, and specific agreements for others, the 
general agreement was used for this analysis. To keep the analysis objective, it was based only on what was explicitly written in the agreement documents.

\subsection{Response rate}

In total, 48 agreements were collected from the target group of 84 publishers. This was a response rate of $57.1 \%$. Of the 48,29 were publishers of the top 100 ISI journals by impact factor. Nineteen of the top 20 publishers of the largest numbers of ISI-rated titles were represented, and 21 were on Ulrichs list of the 53 publishers of the largest numbers of academic refereed titles generally. This doesn't add up to 48 because some publishers were in more than one category. A Venn diagram illustrating the spread of responding publishers across the three groups is given in Figure 4 below. Between them, the target group of respondents published 6,960 academic journal titles (Ulrichs Periodicals Directory 2002). A further 32 agreements were collected from other sources (e.g. the ALPSP mailing) representing a further 342 titles. A total of 80 agreements are therefore included in this analysis. The publishers represented collectively published 7,302 journal titles. According to the Ulrichs Periodicals Directory, there are 39,318 active academic journal titles currently extant (17,556 of which are refereed), so the titles covered by agreements in this survey amount to $18.5 \%$ of these.

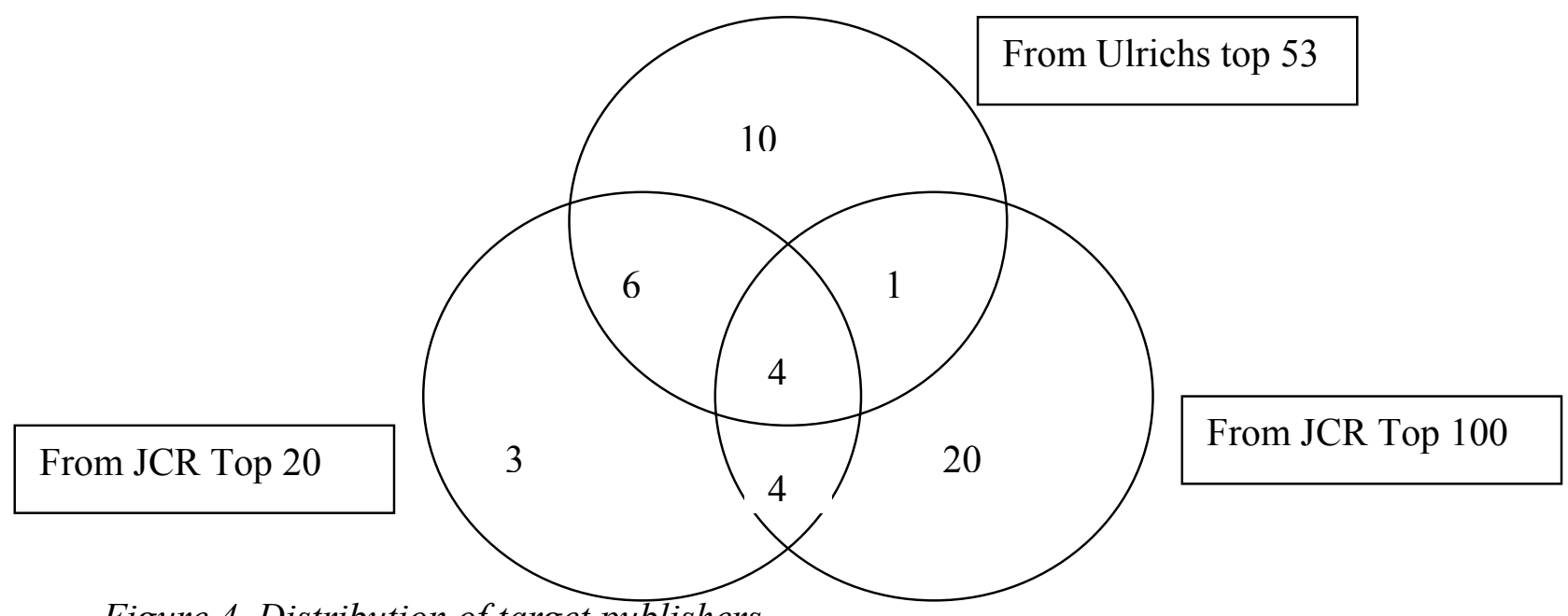

Figure 4 Distribution of target publishers

\section{Ownership of copyright by UK universities}

\subsection{Copyright and patent law}

The UK Copyright Designs and Patents Act of 1988 states that;

11.- (2) Where a literary, dramatic, musical or artistic work is made by an employee in the course of his employment, his employer is the first owner of any copyright in the work subject to any agreement to the contrary. (Great Britain, 1998)

The 1977 Patents Act has a similar clause: 
39.- (1)... an invention made by an employee shall, as between him and his employer, be taken to belong to his employer for the purposes of this Act and all other purposes if -

(a) it was made in the course of the normal duties of the employee or in the course of duties falling outside his normal duties, but specifically assigned to him, and the circumstances in either case were such that an invention might reasonably be expected to result from the carrying out of his duties; (Great Britain, 1977)

Thus the law would seem to grant Universities, as employers, certain rights over the intellectual property created by their employees. In recent times, there has been an increasing interest amongst UK Universities in exploiting some of these rights.

\subsection{Patents}

Perhaps the major interest amongst Universities is the protection of patents. Two recent UK Government white papers (Excellence and Opportunity - a science policy for the 21st century (Department for Trade and Industry, 2000) and Opportunity for all in a world of change (Department for Trade and Industry, 2001)) encouraged Universities to exploit their intellectual property for commercial advantage. The Opportunity for all paper specifically committed to:

...work with Universities UK and the Association of University Research and Industry Links to ensure that universities also improve their management of intellectual property in line with leading private, public and international practice. (Department for Trade and Industry, 2001, Chapter 5, section 29)

The Excellence and Opportunity paper promised considerable additional investment in the development of knowledge transfer initiatives. It also agreed to "change the rules for Government funded research, so that research bodies own the Intellectual Property Rights" (Department for Trade and Industry, 2000). In response to this, the Patent Office funded the creation of a steering group to provide advice to Universities on managing their intellectual property. The resulting guide, Managing intellectual property: a guide to strategic decision-making in Universities (Association for University and Research Industry Links, 2002), despite referring to "intellectual property" in its broadest sense in the title, is exclusively concerned with the commercial exploitation of ideas, principally through patents. There is only a passing mention of copyright in the overview.

\subsection{Copyright in teaching and learning materials}

Despite this preoccupation with innovation, and the protection of innovation through patents, ownership of copyright in the works of employees is now also becoming an issue for UK universities in the area of teaching and learning materials. Institutions are realising that in a global marketplace, the teaching and learning materials currently offered within their own institution could well be exploited externally. The development of the e-University (HEFCE, 2003), to which academics at existing institutions may contribute courses, has further fuelled Universities' anxieties to protect and exploit this previously overlooked tranche of intellectual property rights. 
To this end, in April 2001 the Higher Education Funding Council for England (HEFCE), Universities UK (UUK) and Standing Conference of Principals (SCOP) established a working group to consider the best way of managing these rights (Universities UK/Standing Conference of Principals, 2003). The working group report recommends that IPR in e-learning materials is owned by the Higher Education Institution (HEI), but staff have a royalty-free licence to use it within the HEI. It provides model contract clauses which Universities can use and provides advice on how to manage rights transfer when staff leave.

\subsection{Copyright in research materials}

Despite the increasing interest in some areas of intellectual property, Universities have shown very little motivation to assert their copyright in research outputs such as journal papers, conference papers, and scholarly monographs.

In 2000, the UK JISC Committee for Awareness, Liaison and Training (JCALT) performed a study entitled Policy approaches to copyright in HEIs (Weedon, 2000). A sample of 66 HEIs were asked, "Does your institution waive copyright on any in the list below? [sic]... The largest number of those who waived some of their control, waived copyright on journal articles and books $(80 \%)$, closely followed by personal lecture notes (73\%)..." (p.55). The survey also asked respondents to send their institutional copyright policies in for analysis. Thirty-six did so, thus confirming that "most institutions do waive rights towards scholarly work, with just over half the sample (53\%) acknowledging this in the documentation they sent in." They commented, "it is likely that in other cases rights are effectively waived by custom and practice."

An earlier study by the Intellectual Property Task Force of the American Association of Universities (AAU) in the US expressed concern about a similar lack of interest in this area. The report wrote:

Most research universities already have a set of coherent policies governing intellectual property subject to patent law, mainly developed since the mid 1970s. By contrast, universities have given little attention to intellectual property governed by copyright law even though copyrighted property is used intensively in the classroom, library, and laboratory. (AAU/ARL, 1994)

They drew on some research by Crews (1993) which analysed 39 university copyright policies and found that "in only two instances [was] there a claim to university interest or ownership."

It is something of an irony that in the information age where intellectual property rights are valued so highly, the University IP policies do not ask for additional rights from their employees, or even assert the rights they arguably do have, but instead give those rights away.

\subsection{Why Universities waive rights in research materials}

One of the principal reasons why copyright in research materials has traditionally been waived is because the ability to pursue scholarly research is seen as part of an 'academic's freedom'. The 1909 US copyright act granted a "teacher exception" to 
the principle of a "work made-for-hire". This allowed University faculty to retain copyright in their research. Harper writes:

Many feel that the exception did not survive the 1976 codification, because Section 101's definition of a work made for hire makes no reference to it. Nonetheless, many Universities seem still to honor the tradition of permitting faculty members to own works that might otherwise reasonably be characterized as within the scope of their employment. (Harper, 2001)

Others have called on case law to argue that the "teacher exception" did survive the 1976 Act (Kulkarni, 1995). The Dutch Copyright Act takes a similar line where Universities have rights in publications created for educational purposes, but have to acquire rights in academic publications (Mossink, 1999).

In the UK, neither the 1956 Copyright Act nor the 1988 Act offer the same exception. However, some have argued that if an academic's employment contract does not explicitly state that his or her job description is to undertake research, then any research they perform is not done so "in the course of his employment". Others have said that if the research is performed during the employer's time and using the employer's facilities, then the copyright would belong the employer, regardless of the contract (Law, Weedon and Sheen, 2000). Of course, in reality academic research is probably done partially using the employer's facilities and partly elsewhere. In a discussion paper for the UK JISC, Oppenheim considers this problem:

it is clear that pressures of the RAE has led to a situation where it is arguable that academics are required to create research publications, whether learned journal articles or monographs, and that failure to produce such articles will adversely influence their chances of promotion or tenure within the HEI. Thus, there is an arguable case that research publications are produced by an academic as part of his or her employee duties, and that a strong case can be made that the HEI owns the copyright in such publications automatically, unless there is a contract to the contrary. (Oppenheim, 1996)

It would seem logical that if universities can successfully assert copyright ownership in teaching and learning materials, there is only step from that to asserting copyright in research papers. As Oppenheim's analysis points out, research as well as teaching, are both considered to be core activities for academics.

It is very probable, however, that if a HEI did assert ownership of academic's copyright in research outputs, they would face a great deal of opposition. Not only would there be a history of 'custom and practice' against them, but many academics would vociferously defend their academic freedom if they felt that university ownership of copyright restricted when and where they could publish. The section below on academics' views on copyright ownership explores this concern more fully.

The second key reason why HEIs have not hitherto been interested in retaining copyright in research outputs is because there is no financial gain in doing so. The AAU Task Force report states that "most research is regarded by both faculty and their universities as having no direct market value except where patents may be involved. (AAU/ARL, 1994)" Willinsky (2002) makes the same point. However, 
just because there is no money to be earned, does not mean there is no money to be saved.

\subsection{Universities are encouraged to assert copyright ownership in research outputs}

Proponents of open-access have argued that if only universities asserted their copyright in research outputs, thus prohibiting academics from giving the copyright away to publishers, publishers would not be able to sell access to those copyright materials back to HEIs at such highly inflated prices (JISC Scholarly Communications Group, 2002; ARL, 2000). Such arguments spurred the AAU/ARL to "take a more thoughtful, comprehensive, and purposeful view of copyright matters." They developed four scenarios "for improving the management of copyrights created at research universities".

1) Enhancing current practices - encouraging authors to retain rights for teaching and research purposes;

2) Faculty ownership of copyrights - authors retain all copyright and licence the publisher the necessary rights to publish; the author also manages all other permission requests from third-parties.

3) Joint Faculty/University ownership of copyrights - copyright is shared by faculty member and University in much the same way as patents rights are currently shared.

4) Joint Faculty/Consortium ownership of copyrights - copyright is shared by the faculty member and a consortium of universities.

Oppenheim's discussion paper (1996) recommended to UK HE something like option one: "that UK academics only give publishers limited rights to print publish in the chosen journal, whilst retaining rights for further exploitation, such as use for teaching and electronic publication." It was also "recommended that material should be increasingly offered to non-commercial or University publishers." The Librarian at Yale University drew a similar conclusion. In a Position Paper written in 1998, he recommended an addendum to the existing employment contract that would not be "legally binding", but would "be advisory instead". He wrote:

Even though the University advances no ownership claim to copyrights in most copyrights created at Yale, it is appropriate for the University to urge that copyrights be used to advance education goals. (Bennett, 1998)

The situation in The Netherlands is slightly different in that Universities have no prior claim to copyright in academic publications. Despite this, SURF, the collective of Dutch Universities, has perhaps been the most pro-active in attempting to acquire such rights. A licence agreement has been devised by which authors can licence certain usage rights to their employers. They hope this will form a part of academics employment contracts. They have also developed a model licence for academics to use with their publishers. (Mossink, 1999)

\subsection{Universities' response}

Despite the number of proposals that have been put to Universities, individually and corporately, they have been slow to respond. It is understood that the AAU, while agreeing in principle with the Report's findings, hoped that University Libraries 
would take the proposals forward. However, without the funding to do so, the recommendations failed to make a significant impact on working practices. Bennett's proposal (1998) to Yale met a similar fate. Having put the paper to the University's Committee on Cooperative Research, so the rubric reads, "the Committee... debated the statement but forwarded it to the Provost with neither vote nor recommendation."

In the UK, there has been no co-ordinated move to implement Oppenheim's recommendations. In an informal survey performed by one of the authors in 2002, of 11 UK HE IPR policies, none of them claimed rights in journal articles under section 11 of the Copyright Act. Six expressed a theoretical claim over such rights but then explicitly waived them, and four didn't claim to have any rights in journal articles at all. One policy did not mention copyright in the employer contract.

However, some individuals are currently lobbying their own institutions for a change in practice. This has been particularly motivated by the desire to establish institutional eprint repositories. At the suggestion of one of its law professors, Lancaster University is considering whether it should "claim copyright over research publications to the extent that it reserves the right to authorise free publication, e.g., over the internet, both within and outside the university. (Picciotto, 2002)" Proposals being put to Leeds University suggest:

The University should "ask" or "strongly recommend" that members of staff producing research publications should not sign away their copyright...It should encourage members of staff to contribute their research publications to an Open Archive (Sherpa project, or a discipline-specific one if preferred and where appropriate - Cogprints, ArXiv, etc), where this is possible under the terms of their publication, and to consider using the Harnad/Oppenheim alternative strategy where not (ie archive the unrefereed text and the corrections). (Davies, 2002)

(The Harnad/Oppenheim strategy referred to here recommends that authors make their preprint available while they still 'own' the copyright (i.e., before submitting it to a journal). After refereeing, a corrigenda file containing any amendments should be appended to the preprint. (Oppenheim, 2001)).

The Dutch solution is currently under discussion amongst publishers. Should publishers be agreeable, then the universal HEI/academic agreement will be implemented. However, a more coherent approach to "scholarship-friendly copyright practices" (Anon., 2003) is promised in the form of the Zwolle Principles (2002). The principles have been established as a result of two working conferences on 'Copyright and Universities' in Zwolle, The Netherlands, and they aim to recognise all stakeholders' interests in the division of rights. A conference set for late 2003 hopes to examine how the principles can be put into practice.

The reasons why Universities are slow to respond to such calls are probably the same as the reasons why they tend to waive copyright in the first place. Firstly, there is a fear of being seen to encroach upon academic freedom. Secondly, there is no income to gained by doing so. Thirdly, if Universities own (or license) rights, they may be obliged to do something with them (i.e., license them to third parties etc) and this takes extra resources. However, the mid- to long-term benefits of retaining rights in 
order to create institutional repositories are being much expounded (Crow, 2002). If Universities continue to refuse to assert copyright ownership in research outputs, the onus of copyright ownership decisions and their effect on the ability to self-archive will remain with academic staff.

\section{$4 \quad$ Ownership of copyright by academics}

\subsection{Academics' views on copyright ownership}

In 2002, the ALPSP published a report entitled Authors and electronic publishing. In it, they asked academics who they thought owned the copyright in research papers.

Seventy-nine per cent said they thought it was the author, $17 \%$ said their institution or company, and the remaining 4\% said the matter was disputed (Swan, 2002). The response to the RoMEO survey question, "At your institution who owns the copyright in your research papers?" is illustrated in Figure 5 below.

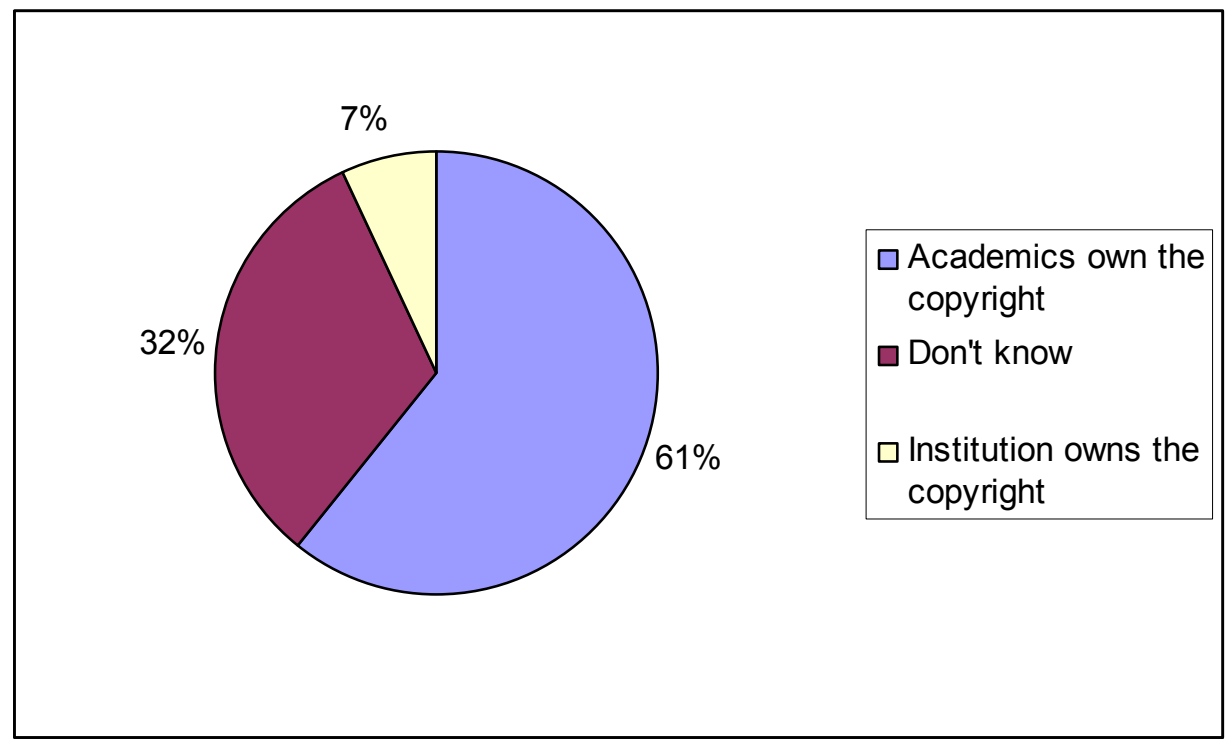

Figure 5 Opinion on copyright ownership of research papers author

The RoMEO survey found a less confident sample, with one-third admitting that they did not know. Even so, the majority of respondents (61\%) believed that academics owned the copyright in their research papers. Seven per cent thought that the institution owned it.

Weedon's research (2000) asked a similar question of a range of academics by telephone interview. The response was interesting:

Most admitted to never having really considered this issue. Indeed, when asked about research papers being written up for publication, many could not relate to this question at all, thinking that it related to the transfer of ownership between the academic and the publisher. Similarly, most were amazed to learn that their institution might have legal ownership of their work... None, however, were particularly upset by this revelation and none had any idea of whether their institution officially waived these rights. 
It is hardly surprising that academics know nothing of their institution's copyright policy; $25 \%$ of institutions surveyed by Weedon had no formal policy (p. 52). Often policies are buried in Staff Handbooks and are unlikely to be sought out and read. As academics are expected to win research funding and to publish in scholarly journals, it is a logical assumption that they have the right to assign copyright to those journals when asked.

Despite Weedon's finding that respondents were not upset by the revelation that they may not own copyright, the fact remains that this is an issue for many academics. In the UK, Cambridge University is attempting to introduce a new policy that takes control of much of the intellectual property generated by its faculty. Even though the policy does not include "normal academic forms of publication" (Baty, 2002), it has caused an uproar amongst the faculty (Evans, 2002). In the US, an article by Kulkarni (1995) takes a similar line to the outraged Cambridge academics and argues that faculty should own not just copyright, but patent rights as well. He writes, "all creations by university faculty should be valued equally because no genre of creation is intrinsically better than another".

The relationship between author and work has been considered by many a legal and literary philosopher and is beyond the scope of this study. However, suffice to say that many suggest the bond goes deeper than simple property ownership. Mark Rose (1993), in Authors and Owners: the invention of copyright, writes:

The institution of copyright is of course deeply rooted in our economic system and much of our economy does in turn depend on intellectual property. But, no less important, copyright is deeply rooted in our conception of ourselves as individuals... and it is associated with our sense of privacy and our conviction, at least in theory, that it is essential to limit the power of the state. We are not ready, I think, to give up the sense of who we are.

Even though there may be some truth in such beliefs, the fact remains that academic writing is in many ways quite different to other forms of authorship. As Francois van Schalkwyk (1998) points out, a post-structuralist view of authorship moves away from the Romantic notion of lonely author toiling away in a dusty garret, and towards author as compiler - building with others upon work that has gone before. This is certainly a more accurate description of academic writing where joint authorship and the use of third-party material is common (see below). Indeed it is perhaps this modern view of authorship which explains one of the JCALT report's findings, namely, a different approach by newer and more established members of academic staff to the issue of copyright ownership:

Younger members of staff see their department as a 'business unit'; they anticipate a more managerial climate and hence they expect that the institution will take ownership of all outputs. This is in contrast to older members of staff who see their main loyalty as lying with their subject discipline...older staff assume that they own the copyright of journal articles and books which they have written, prior to publication. (Weedon, 2000) 


\subsection{Multi-authored papers}

The issue of joint authorship is an important one in the copyright ownership and selfarchiving debate, and not just for the philosophical reasons outlined above. In such cases, for the paper to be made freely available on an institutional repository, all authors would need to agree to it. The more authors, the more likelihood for disagreement on this matter. RoMEO survey respondents were asked to indicate what percentage of their papers had more than one author. The responses of the 537 answering this question are given in Figure 6 below.

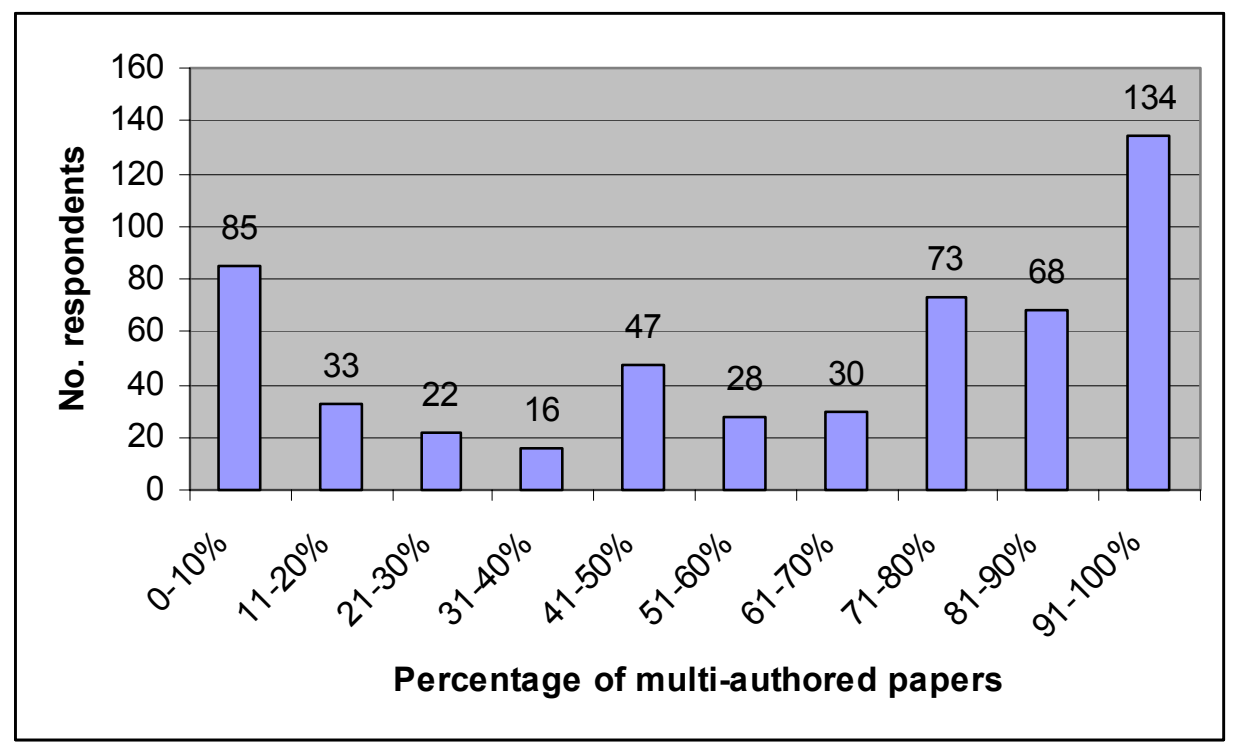

Figure 6 Research papers with more than one author

Fifty per cent of respondents fell into the top three categories, indicating that $71-100 \%$ of their papers were multi-authored. Indeed, $25 \%$ of respondents (134) fell into the $91-100 \%$ category. Of that 134 , exactly $100(75 \%)$ indicated that all of their papers were actually multi-authored. There was a fairly even distribution among the $11-70 \%$ categories with another peak in the $0-15 \%$ category. Of the 85 respondents in this latter group, only $17(20 \%)$ stated that none of their papers had more than one author.

The recent UK White paper, The Future of Higher Education made the point that "modern research is less amenable to the "lone scholar" model - for example one study found that by 1994, 88 percent of all UK HEI papers involved two or more authors and 55 percent involved two or more institutions." (Department for Education and Skills, 2003). The numbers are similar in the US (NSF, 2002). Indeed, in some disciplines the increase in joint authored papers is generating a debate as to what actually qualifies for authorship (ICMJE, 2001).

Thus there are two issues here. Firstly, for a multi-authored paper to be self-archived, all authors (as copyright owners) will have to agree on that course of action. They will need to consider whether to archive the pre-print or the postprint, and on what approach to take with the publisher. They may have to agree to use a 'self-archivingfriendly' publisher, or to an alternative form of wording to the publisher's transfer agreement. A second issue arises if the authors are from more than one institution. If a relevant subject-based repository exists the paper could be mounted there. If not, authors may need to lodge copies with a number of different institutional, or other, 
repositories. This is not so much of a problem for a post-print which is in its final form. However, if the authors mount their preprint, they will need to make sure the copies in each individual repository are all updated with information on the published version when it becomes available.

\subsection{Third-party copyright}

Another issue that affects the copyright ownership status of academics' research papers is the quantity of third-party content they contain. Respondents were asked if they had ever had to clear third-party copyright in order to publish a paper. Fivehundred and twenty-seven responded. Of these $25 \%$ (132) said they had cleared third party rights in order to publish a paper, while $75 \%$ had not. This raises different issues for the self-archiving of unpublished and published papers. Authors of as-yetunpublished papers would need to get the third-party's permission not only to publish in the journal of choice, but also to make the material freely available on the web. The third-party may be happier with the former than the latter. Authors that wish to self-archive previously published papers would need to clear the same rights with third-parties retrospectively.

\subsection{Copyright assignment}

An ALPSP (1999) survey entitled What authors want, showed that " $61 \%$ of respondents thought that copyright should remain with the author, rather than being signed over to the publisher". The RoMEO author survey asked respondents whether in the main, they assigned their copyright to publishers in order to get published. Four options were given: Yes, freely; Yes reluctantly; No, most publishers I work with don't ask for copyright assignment, and No, I insist that I retain copyright.

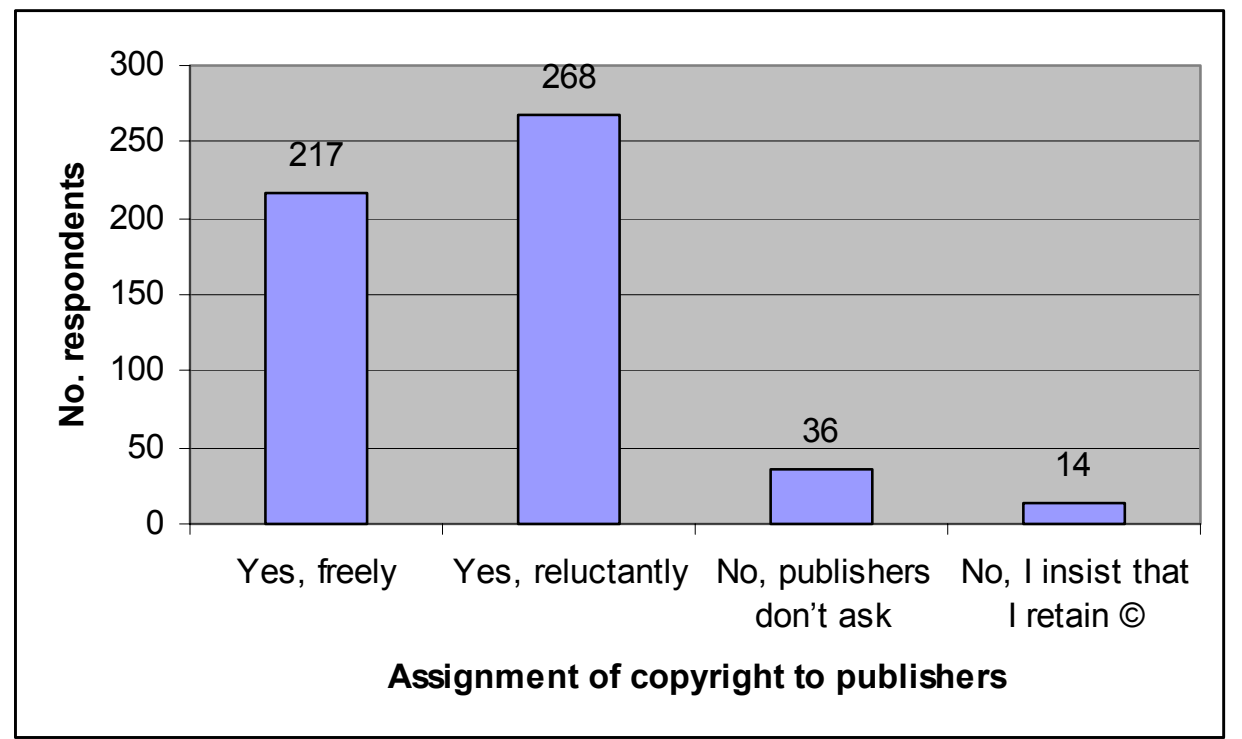

Figure 7 Academic author willingness to assign copyright to publishers

The largest group (49\%) of respondents said that they reluctantly assigned copyright to publishers. Forty-one per cent said that they did so freely. Only a handful (7\%) said that the publisher did not ask for it, and fewer $(3 \%)$ insisted on retaining copyright. 
Thus it seems that while academics are unhappy with the thought of their institutions owning copyright, a good proportion of them are happy to relinquish it in exchange for publication. As Morris (2000) has noted with regards to the ALPSP survey, "the ability to retain copyright was not a deciding factor in an author's choice of journal." However, she goes on to recognise that the tide is turning.

Hunt (2002) has performed a survey of users and non-users of two major eprint archives; ArXiv and Cogprints. On the subject of copyright concerns she found the following:

Comments made by [ArXiv users] concerning copyright issues suggested that they were generally unsympathetic towards the dictates of the journal. 61 out of 389 responded and of those, $25 \%$ stated they avoided journals that do not allow an author to archive their work, and a further 30\% stated they felt they should retain copyright to their own work. [Cogprints non-users] feel the journals have more control over authors, with 31 of 166 responding and of those, $26 \%$ stating they feel that copyright constraints limit them in archiving papers. Of [Cogprints users], 21 out of 166 responded and of those, 50\% stated that they were aware of problems but archive anyway.

This concurs with further findings from the ALPSP (1999) survey where authors generally favoured publishers that were willing to allow them to self-archive the postprint online (25\% said this was very important to them and $34 \%$ said it was important). Twelve per cent said they would not abide with publishers' policies forbidding them from making articles freely available online.

\subsection{Alternatives to copyright assignment}

Respondents that did not assign copyright were asked to explain what they did instead. They were given three options and an "other" category. The options were: "I sign publishers' exclusive licence agreements"; "I amend the publishers' copyright assignment form and return it", and, "I use my own licence agreement that I send to the publisher".

Fifty respondents indicated in the previous question that they did not assign copyright (either because they were not asked or because they insisted on retaining it). Fiftyone responded to this question. None indicated that they used their own licence. The other responses are illustrated in Figure 8 below. 


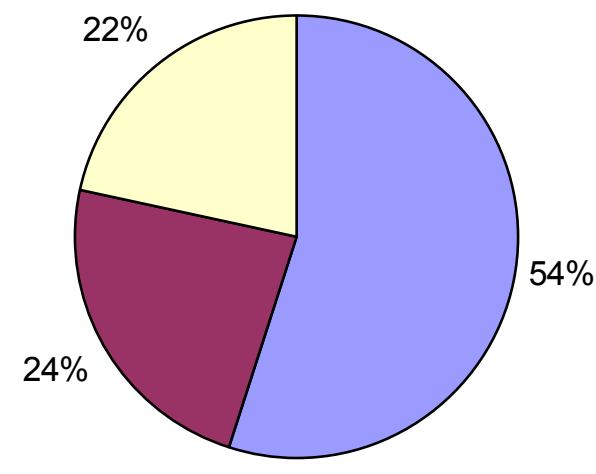

$\square$ Sign exclusive licence

Amend Publisher's

licence

$\square$ Other

Figure 8 Alternatives to copyright assignment

To satisfy academics' desire to retain copyright, a number of publishers appear to be introducing exclusive licences as an alternative to copyright assignment (see section 5.3 below). (An exclusive licence asks authors to assign certain rights on an exclusive basis to the publisher, rather than asking for the transfer of copyright outright). Interestingly, the majority (54\%) of respondents that did not assign copyright said that they signed exclusive licence agreements instead. However, in practice exclusive licences can be equally as restrictive as copyright assignment forms. Thus, while academics want to retain copyright in principle, it seems that they are not aware of what this means in practice.

The evidence suggests that there is some confusion amongst academics regarding the oxymoron of 'intellectual property' (Guedon, 2001). The majority think they own it and see themselves as the rightful owner rather than their institution. However, $90 \%$ still assign copyright in exchange for publication, albeit reluctantly in $50 \%$ of cases. The majority of those that retain copyright sign exclusive licence agreements instead, most of which are equally as restrictive as copyright assignment forms. The question is, what is it about an exclusive licence that makes it so much more attractive to authors than copyright assignment? What is it about copyright that they wish to retain?

It would appear that academics are more concerned with the intellectual of intellectual property, than the property. That is, they are more interested in their moral rights over their work, than any economic rights. They see their work as an extension of themselves in an intellectual sense, and not an extension of their portfolio in an economic sense. This is understandable, as it is rare indeed for an academic to be paid for a journal article. We of course recognise the argument that a large number of publications can lead to academic tenure or promotion, which in turn leads to income. Nevertheless, we believe that the primary value of an article to an academic is its intellectual value and resulting kudos. Thus, when faced with an agreement that asks for an exclusive licence to deal with the work, and that insists that "copyright remains yours (ALPSP, 2000)" the author happily signs. It is often not until the Library returns their multiple photocopying request with a note to the effect that their budget 
will not cover the permission fees, that academics see the significance of retaining rights to deal with their work (Gadd, 2002). Academics are often unaware that copyright, as well as offering protection for moral rights (in some cases) also grants them a series of exclusive "economic" rights to deal with the work, and if these are assigned on an exclusive perpetual basis, they are no better off than if they had assigned copyright itself.

\section{$5 \quad$ Copyright ownership by publishers}

\subsection{Copyright law and publishers}

The Licensing Act of 1662, precursor of copyright law, was introduced as a means of censorship and to protect the investment of presses in the printing process. Over time however, the focus of copyright protection has shifted from the publishers in favour of the original creators of 'intellectual property', in this case, authors (Guedon, 2001). UK copyright law now only protects publisher investment in the scholarly communication process by granting them copyright in the typographical arrangement of a work (or in the case of databases, database rights). How then are publishers to protect their investment? Fortunately, as the former Chair of the Publishers Licensing Society, Maurice Long (1998), made note; "the international convention in journal publishing is one publication only, one time only." Therefore, he continues;

Most journals have a policy of requiring transfer of copyright or an exclusive licence or of refusing articles which are about to be, or have been published elsewhere. This is in order to preserve the integrity of scientific research publication; anything else would lead to bibliographic chaos.

Of course, obtaining copyright transfer in the interests of maintaining bibliographic order and scientific integrity also has an additional benefit: an economic monopoly over the resulting published work. Any detractions from this monopoly, Long argues, thus limiting "the chance of reasonable exploitation by the journal publisher, either by time, platform or format, would render the process of journal publishing non-viable." Thus, publishers ask for copyright assignment.

\subsection{Copyright assignment required by publishers}

In the RoMEO journal publisher Copyright Transfer Agreement (CTA) analysis, 72 of the 80 agreements $(90 \%)$ asked authors for copyright assignment. The statements used by which authors assigned copyright varied from the long exhaustive clauses through to single phrases such as "I/we hereby assign to [Publisher Name], full copyright in all formats and media in the said contribution". One more lengthy clause read:

Journal Contributor assigns to the Publisher all right, title and interest, including copyright and all rights under copyright, throughout the world, in and to the Article, including without limitation the exclusive right to publish, perform, display, reproduce, distribute and sell the Article and to create derivative works, in all forms or media now known or hereafter developed, including without limitation print, electronic and on-line media, in all languages throughout the world, and the right to license or authorize others to do all of the foregoing. To the extent that any right now or in the future existing is not specifically granted to 
Publisher by the terms of this Agreement, such right shall be deemed to have been granted hereunder.

Historically, publishers have had no difficulties in getting authors to assign copyright. Indeed, the situation has been so little of an issue that, as Page, Campbell and Meadows (1997) noted,

Publishers are sometimes lax over copyright in that they assume that a statement in the notes to contributors, such as 'on acceptance of a paper for publication it becomes the copyright of the journal', is sufficient.

In a letter to members of the ALPSP, Oliver (1998) made the point that, "most authors will assign their copyright automatically, with surprisingly little or no thought". However, as the serials crisis has worsened in the academic community and the debate about copyright ownership has found new protagonists in the form of academic staff, publishers' views have changed. As Bammel (1999) notes,

A learned journal is dependant on the articles submitted by authors. Publishers want to ensure that their journals remain the preferred vehicle of publication of academic research. To achieve this, publishers must... understand and address the needs of their author community...

As noted above, a recent ALPSP (1999) survey has shown that the majority of authors want to retain copyright. So how are publishers responding to this increased interest in copyright ownership amongst academics?

\subsection{Publishers' response to academics' desire to retain copyright}

One response, as previously mentioned, is a move away from copyright assignment forms to exclusive licences. In his Principles of good practice in scholarly journal publishing, Bammel (1999) states,

"It is not always essential that the author transfers copyright to the learned society or other publisher; an exclusive grant of the necessary publication and sublicensing rights may be adequate."

Indeed, the model publisher/author agreement produced by the ALPSP (2000) takes the form of an exclusive licence.

The RoMEO survey found that four of the 72 publishers asking for copyright assignment also gave authors an alternative option of signing an exclusive licence agreement. Five of the remaining eight just asked for an exclusive licence and three asked for a non-exclusive licence (see Figure 9 below). 


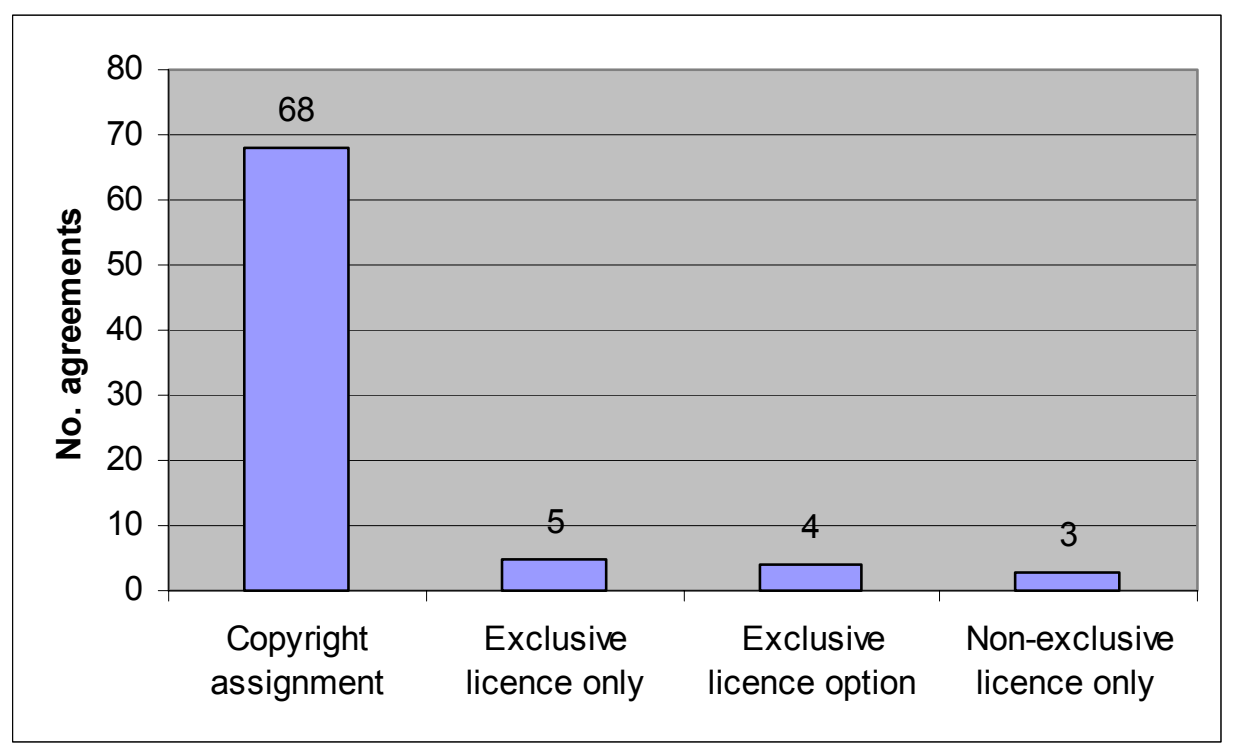

Figure 9 Copyright assignment vs copyright licences

However, the clauses by which authors were asked to grant exclusive licences to publishers were no less lengthy or exhaustive in the rights they required through copyright assignment forms. One exclusive licence statement read as follows:

You hereby grant to [Publisher Name] a sole and exclusive licence for the full period of copyright throughout the world: to reproduce and/or distribute the Article (including the abstract) throughout the world in printed, electronic or any other medium whether now known or hereafter devised, and in turn to authorize third parties (including Reproduction Rights Organizations such as the Copyright Licensing Agency), to do the same; to publish the Article in the above Journal, and sell or distribute it within the Journal, on its own, or with other related material; to grant permission for photocopying or electrocopying versions of the Article published by [Publisher Name]; and to republish and to give third parties permission to republish the Article or parts thereof in any medium including without limitation in printed form, microform, database, CD-ROM, and other forms of electronic publications and/or transmission, now known or hereinafter invented.

A possible reason for the length of exclusive licence clauses is that publishers asking for exclusive licences have to spell out exactly what rights they need to perform their business. In contrast, publishers that have had copyright transferred to them have their rights spelled out by copyright law. Far from meeting academics new-found desire to retain copyright, exclusive licences are copyright assignment by another name. Indeed, the Page, Campbell and Meadows (1997) text book on Journal publishing advises publishers themselves that, "the licence to reproduce material should never be given on an exclusive basis...".

Another response to calls for copyright retention by academia is explained by Page, Campbell and Meadows (1997):

Publishers have naturally responded...by emphasising that their organising of the supply of information adds value to it, and that this added value itself 
requires protection. They are arguing, in effect, that there exists a 'publisher's right', which should run in parallel with author's rights.

This is a perfectly legitimate argument, and not one that any proponents of openaccess would take issue with. The fact, as mentioned section 5.1 above, that publishers have no legal stake in the copyright works they publish other than a right in the typographical arrangement, leaves their other value-adding efforts unprotected. Arguably, if publishers had proper legal protection for their contribution to the scholarly communication process, there would be no need for them to ask for a share of their authors' rights.

We found that three agreements explicitly stated that substitute forms or amendments to the agreement document were unacceptable. In the worst case scenario, such forms would be rejected; at best they would considerably slow down the publication process.

The final response from publishers has been the introduction of 'explanatory notes' for authors about copyright assignment. In Oliver's (1998) note to the ALPSP, she wrote:

It is...apparent, that an increasing number of authors are concerned that by assigning their copyright they are being asked for some nefarious reason to forfeit their proprietary rights....We [the ALPSP Copyright Committee] felt that it was good practice to provide some explanatory notes for authors, to accompany the actual form they are required to sign.

Our CTA analysis investigated how many forms had actually taken this advice on board.

\subsection{Why publishers require copyright assignment}

Thirty-six of the agreements (45\%) gave an explanation as to why copyright assignment or licence was required. Nineteen others gave no specific reasons, but did include in their copyright assignment statement wording to the effect that copyright was being assigned 'in consideration of' reviewing, editing and/or publication. However, as Page, Campbell and Meadows (1997) have pointed out, "whether these are legally acceptable as 'considerations' has not been examined in the courts." The remaining 25 (31.2\%) gave no explanation at all.

The main reasons given by the 36 offering an explanation are illustrated in Figure 10 below. 


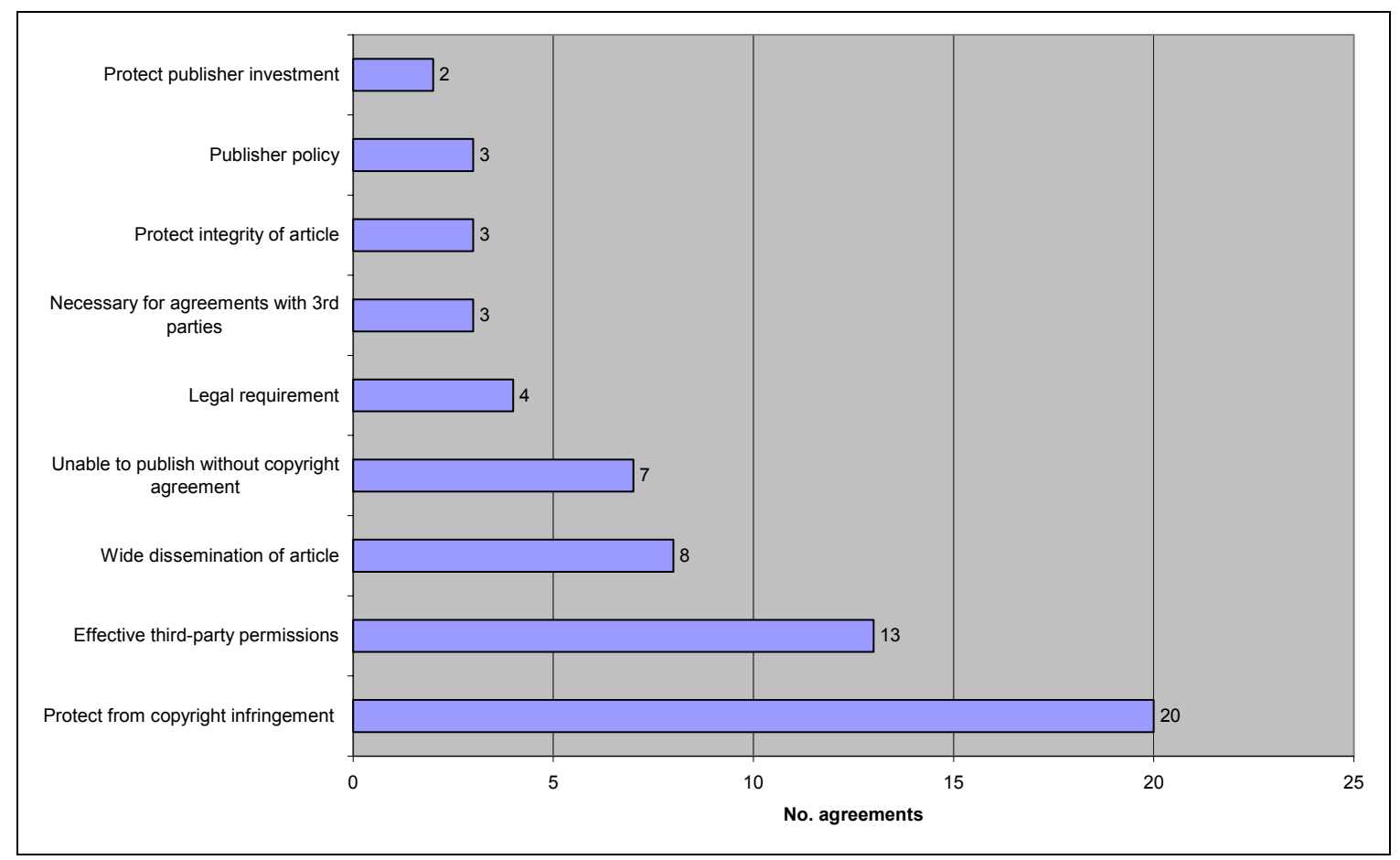

Figure 10 Reasons for requiring a copyright agreement

\subsubsection{Protect against infringement}

The most popular reason was to protect against copyright infringement. Bammel's (1999) guidelines state that "Publishers have a moral responsibility to protect their authors' work from misappropriation or distortion by others and to act against any infringements irrespective of copyright ownership." However, other than suggesting that "technical protection, such as encryption or digital watermarks, may sometimes be appropriate", he gave no advice as to how this moral responsibility should be carried out. None of the CTAs explained how they proposed to do this either. Although publishers may be in a better financial position than an individual to bring a law suit against an infringer, it is unlikely that many publishers actively seek out such cases, and instead wait until they are brought to their attention.

\subsubsection{Effective third-party permissions}

Facilitating effective third-party permissions was the second most popular response. This is indeed a benefit to both authors and permission-seekers in the current publishing model, saving the latter from having to locate the former, and saving the former from being bothered by the latter. However, if the whole model is shortcircuited by authors making their papers freely available on the web (perhaps under explicit terms and conditions supplied by rights metadata), then permission no longer needs to be sought; ergo, the permission process needs no facilitation.

\subsubsection{Wide dissemination}

Eight agreements explained that copyright assignment was required to guarantee wide dissemination of the article. However, as Lawrence's (2001) much-cited Nature article has shown, "articles freely available online are more highly cited". As CTAs often prohibit the making of articles freely available online, it seems ironic that they claim to improve dissemination. 


\subsubsection{Legal reasons}

Statements relating to US copyright law could mislead authors into thinking that copyright transfer is a legal requirement. Section 204(a) of the US Copyright Law states that,

"A transfer of copyright ownership, other than by operation of law, is not valid unless an instrument of conveyance, or a note or memorandum of the transfer, is in writing and signed by the owner of the rights conveyed or such owner's duly authorized agent. (US Copyright Office, 2001)"

It does not state that publishers have a legal requirement to obtain copyright transfer before they can publish. It only states that if copyright transfer does take place, it must be in writing. Those agreements that state that the publisher 'cannot publish' without a copyright assignment form are similarly misleading. The publisher can publish without a copyright assignment form, they just choose not to. The agreements that state that it is 'publisher policy' to obtain copyright transfer are being more open, even if they give no explanation for their policy. It was surprising that more publishers were not upfront about the need for copyright assignment in order to protect their own investment.

Interestingly, no agreements explicitly stated that copyright transfer was necessary for the quality control process - one of the few aspects of scholarly publishing that the self-archiving model has no real alternative to as yet, and arguably the most important value-added service the journal publisher provides.

\subsection{What happens when authors cannot assign copyright?}

In certain circumstances, authors will not be in a position to assign copyright to journal publishers. Copyright in work produced by employees as part of their employment (known as 'work-for-hire' in the US) may belong to the employer. Also, in some countries, work produced by government employees is governed by different copyright rules. In the US, government-owned works automatically belong in the public domain and are not protected by copyright law. Crown copyright in the UK subsists in works made by the Queen or "an officer or servant of the crown in the course of his duties" and is owned by Her Majesty the Queen. The analysis ascertained how many agreements recognised the above scenarios and what provisions were made for them.

Forty-four agreements (55\%) made provision for copyright works owned by an employer (other than government-owned public domain works). Twelve of these gave employers more liberal terms than authors were offered. In seven cases, employers were only asked for a non-exclusive licence, usually just to publish and deal with third-party requests. In the other five cases, employers still had to sign the copyright agreement, but were granted more exceptions to use the work than authors would have been granted. In the 32 other agreements where work-for-hire provisions were made, the employer simply had to sign either instead of, or as well as, the employee.

Forty-six agreements (57.5\%) explicitly gave options for US government owned works and 17 for crown copyright. However, other agreements may have encompassed government-owned works under their "Work for hire" option. 
The fact that publishers are willing to publish government-owned works even though they may also be available in the public domain, and are willing to recognise employers' ownership rights more generously than they are authors' rights, is quite significant to the open-access movement. Such scenarios show that copyright assignment is not, and can not be, an essential pre-requisite to formal journal publication, and that non-exclusive licences will suffice and are tolerated.

In the case of government-owned works that may be published both in a journal and in the public domain, there is a direct parallel with self-archived works which hope to be published by two separate means. Of course, publishers have no choice but to recognise 'work-for-hire' and government-owned works because they are instituted in legal statutes. However, publishers are not obliged to publish works that fall into these categories. The fact that they do indicates that they do not really need copyright to publish as they suggest, but that they require it for other financial reasons.

In a guest editorial for Learned Publishing, entitled, "Authors and copyright" Morris (2000) debates, "what rights does the publisher actually need?" She concludes:

"Clearly, they need the right to publish in print and, increasingly, electronic format; this should be an exclusive right to avoid both competition and potential confusion (e.g. duplicate publication). They also need the right to grant licences to other people (such as the Copyright Licensing Agency...). Publishers have often argued that they need copyright, both in order to protect their and the author's rights in case of any infringement, and to simplify the processing of permissions requests. However, it is perfectly possible (with the author's permission) to act on her behalf in defence of copyright; the publisher can also undertake the processing of permissions requests on the author's behalf. It is therefore hard to find a justification, other than convenience, for insisting on taking the author's copyright."

The problem with exclusive licences from the point of view of authors as recommended by this editorial, has been dealt with above. Despite arguing that the right to publish should be an exclusive one, Morris goes on to encourage publishers to allow self-archiving. Those that have allowed self-archiving have not "seen any damage to their journals; if anything, it probably achieves increased visibility", she writes. Asking for an exclusive right to publish on the understanding that the right is not exclusive because the author is allowed to self-archive, is to an extent selfdefeating. However, it is one solution to the copyright ownership battle that could facilitate self-archiving.

\subsection{Publisher attitudes towards self-archiving}

As suggested by the Morris editorial, the success of self-archiving would not be hampered by publishers acquiring copyright from authors if they subsequently licensed authors the right to self-archive. Bammel's (1999) guidelines state:

"Even in circumstances where copyright is transferred, publishers should grant back to authors a broad range of rights which enable them freely to do the things which are important to them:" 
As reported in section 4.4, the 2002 ALPSP survey on Authors and electronic publishing showed that $59 \%$ felt that the ability to self-archive a post-print online was either important or very important to them. However, the RoMEO CTA analysis showed that just $42.5 \%$ of publishers (representing $49.1 \%$ of journal titles) allow selfarchiving. (An updated listing of publisher CTAs with regard to self-archiving is maintained on the RoMEO Project web site (2003).)

\section{Summary of copyright ownership options}

The views of universities, academics and publishers regarding copyright ownership have been considered. Although the samples of the academic author survey and the journal CTA analysis were small and therefore do not provide conclusive evidence, they provide a strong indication of current thinking. Morris (2003) has suggested that who actually owns copyright is somewhat irrelevant if every party in the chain has the right to do what they want to do. However, with regard to self-archiving the current model of copyright ownership by publishers as illustrated in Figure 11 below (the shaded box indicates copyright ownership), leaves the rights of some parties unsatisfied. Authors or institutions that wish to self-archive are, in $50 \%$ of cases, unable to do so.

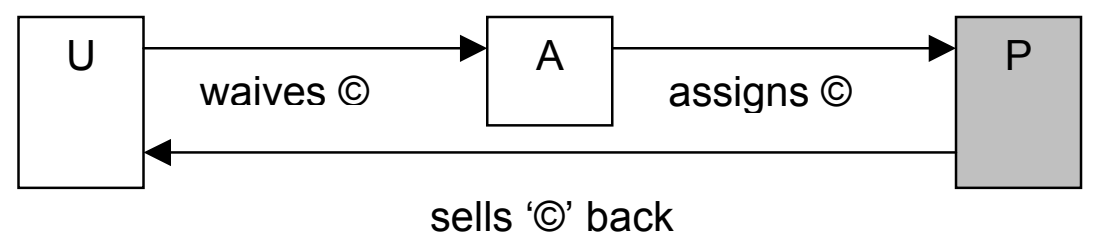

Figure 11 Publisher ownership of copyright

It has been demonstrated that it is not essential for publishers to acquire copyright in order to publish, so copyright need not rest with them. Most institutional repository models rely either on liberal publisher CTAs that allow the author to self-archive, or on the author retaining copyright and simply licensing the publisher the right to formal journal publication. The latter model is represented in Figure 12 below.

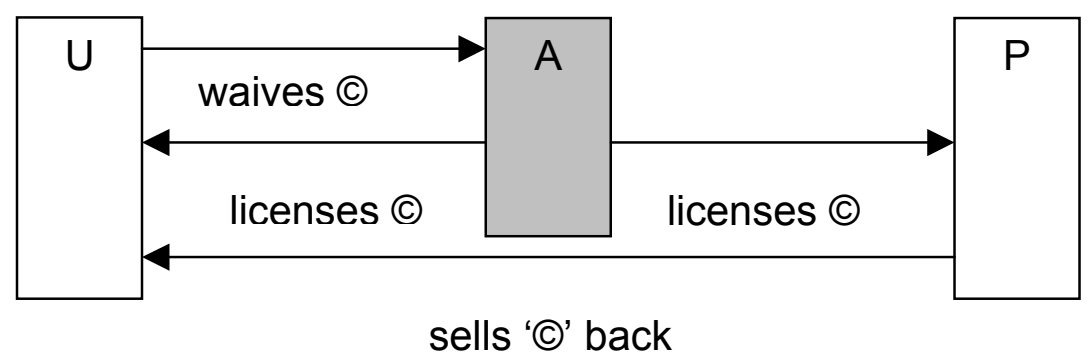

Figure 12 Academic ownership of copyright

This does not make sense because the University is giving something away that it needs. It is giving away the rights it needs to archive papers on an institutional repository. As a result, academics need to license both publishers to publish and universities to archive. That is not necessarily a bad thing as academics are the 
original creators and owners of the intellectual property in question. However, this paper has questioned the level of understanding amongst academics as to what copyright actually is and what rights it gives them under law. Also, our survey has showed that $41 \%$ of academics are happy to assign copyright: what then would motivate them to retain or licence it? As individuals, academics may also be in a weaker position to negotiate a licence with a publisher instead of copyright assignment. Theoretically, a better solution would be for universities to retain copyright themselves. This model is shown in Figure 13 below.

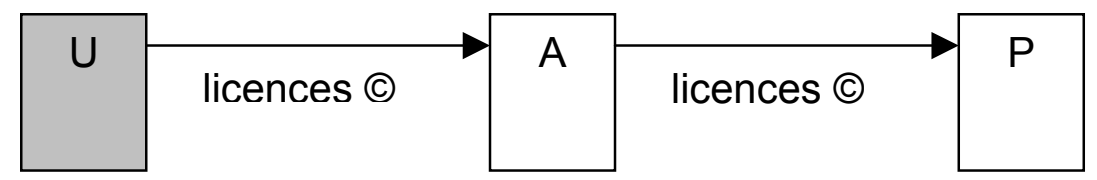

\section{Figure 13 University ownership of copyright}

This model is identical to the model proposed by the UUK/SCOP Group's recommendation for the IPR in e-learning materials (Universities UK/Standing Conference of Principals, 2003). The University retains copyright and licences academics the right to licence publishers the right to formal journal publication. This model makes more sense for universities wishing to archive the research output of their academic staff. However, as this paper has shown, academics have a strong interest in retaining copyright ownership. Perhaps a more acceptable model would therefore be shared copyright ownership between university and academic (see Figure 14 below).

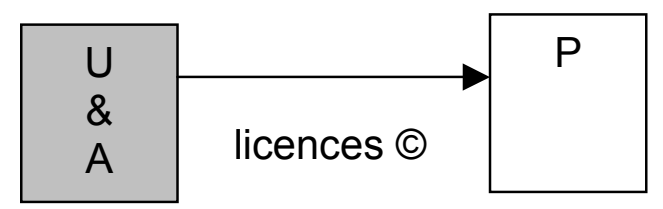

Figure 14 Joint University and academic ownership of copyright

This model compares with many university IP agreements for patent rights, and is clearly the shortest and simplest chain. However, it implies that resources must be devoted to managing the $U$ and A relationship to everyone's satisfaction.

\section{$7 \quad$ Recommendations}

\subsection{HEIs}

Although University ownership of copyright seems like a logical move in principle, it would be a dramatic cultural shift in practice. As this paper has demonstrated, despite many calls for universities to show an interest in the copyright management of research output, very few have answered them. It would seem sensible therefore, to build a bridge of recommendations by which universities may incrementally move towards a copyright management policy that better benefits both themselves as an institution, and research as a whole. 
A logical first step would be to simply amend IPR policies to show that the university does consider itself the rightful owner of copyright under law even if it chooses to waive that right for the time being. This would at least provide universities with the legal basis by which to shift their policies at a future date (Law, Weedon and Sheen, 2000, p.142). The ultimate goal would be the retention of a non-exclusive right to utilise the work for university purposes - including archiving on an institutional repository. In the meantime, universities should play a greater role in educating, informing and advising academic staff as to their copyright assignment and licensing options. They should also encourage and facilitate the retention of copyright by academic staff through the creation of promotional materials, sample agreements and clauses they may wish to use with publishers, and lists of freely available electronic journals and 'self-archiving-friendly' publishers $\left.{ }^{1}\right]$.

\subsection{Academics}

One of the best pieces of advice for academics wishing to retain copyright for selfarchiving purposes is to beware of exclusive licences. They may be equally as restrictive as copyright transfer agreements. Where possible, academics should consider publishing in open-access journals or those with non-exclusive licences. However, if there is no alternative to copyright assignment, the academic should check agreements to see whether self-archiving is permitted, and if not, negotiate for such permission.

Options for academics with regard to self-archiving options and copyright assignment are complex and depend on whether

a) they want to self-archive preprint, postprint or both;

b) copyright assignment is required pre or post-refereeing;

c) whether the copyright assignment form allows self-archiving of preprint, postprint, both or neither.

(The issues relating to (b) and (c) will be discussed in the third of the RoMEO Studies series in the light of relevant data from the Journal CTA analysis. See below for details.) Figure 15 below shows a diagram of the publishing process, where selfarchiving of the preprint or postprint should occur, and the effect of different CTA's on the process. Whether self-archiving the preprint or post-print, it is preferable if this is done prior to signing the CTA. Once copyright has been transferred, selfarchiving might not legally be permitted (depending on the wording of the CTA). However, self-archiving that occurs prior to copyright transfer is not subject to that agreement. That is not to say that the publisher is duty bound to accept a manuscript that has been self-archived $\left[{ }^{2}\right]$, but simply that the act of self-archiving itself has not infringed the terms of the agreement. 


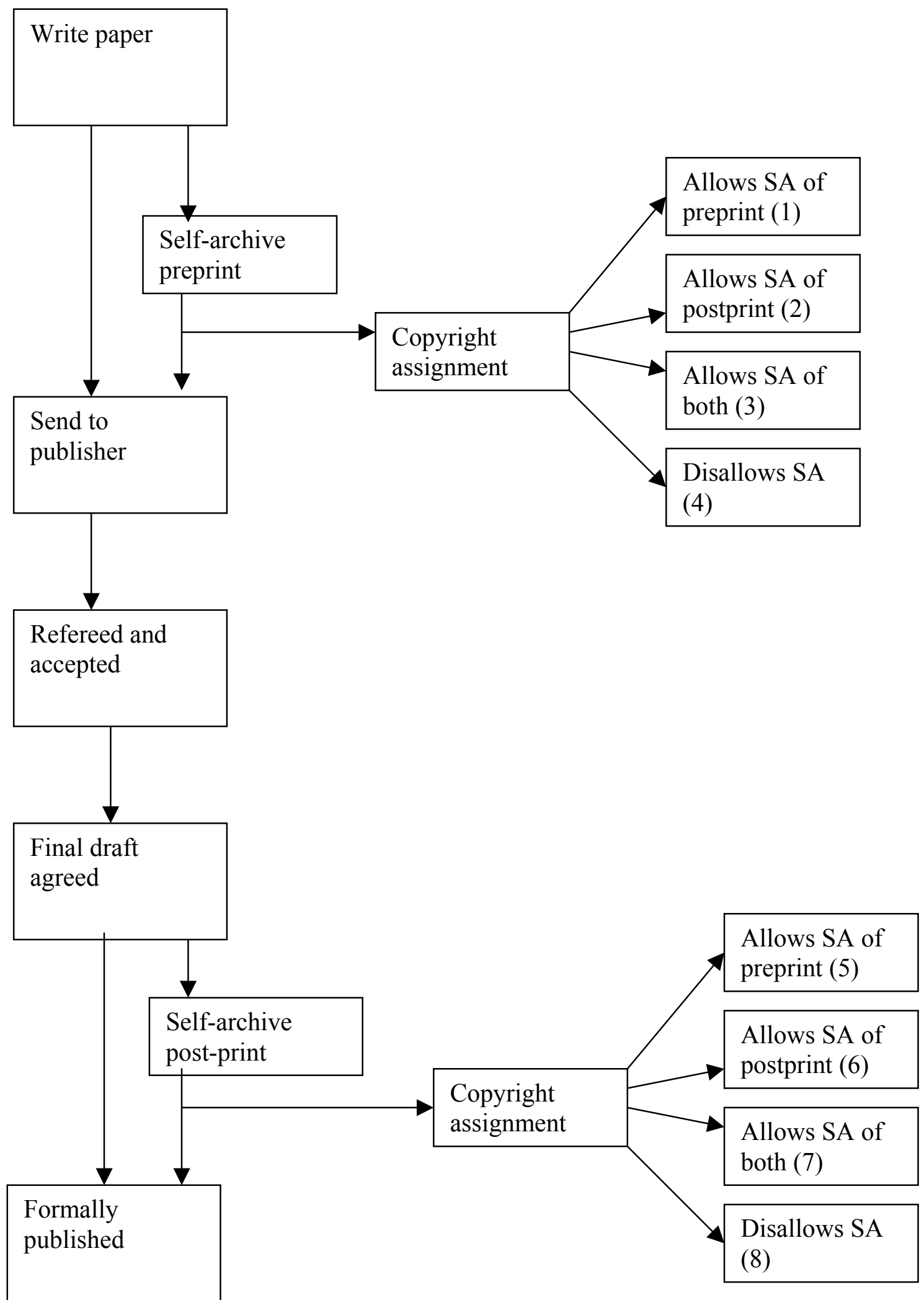




\begin{tabular}{|l|l|l|}
\hline Option: & \multicolumn{1}{|c|}{ To self-archive the preprint } & \multicolumn{1}{|c|}{ To self-archive the post-print } \\
\hline$(1)$ & No problem & Not applicable \\
\hline$(2)$ & $\begin{array}{l}\text { May not accept manuscript if its been } \\
\text { self-archived. May negotiate. May ask } \\
\text { for it to be removed. }\end{array}$ & No problem \\
\hline$(3)$ & No problem & No problem \\
\hline$(4)$ & $\begin{array}{l}\text { May not accept manuscript if its been } \\
\text { self-archived. May negotiate. May ask } \\
\text { for it to be removed. }\end{array}$ & $\begin{array}{l}\text { Will not be able to self-archive post- } \\
\text { print without negotiation. }\end{array}$ \\
\hline & \multicolumn{2}{|c|}{ If copyright assignment required post-refereeing } \\
\hline$(5)$ & $\begin{array}{l}\text { No problem } \\
\text { May not publish if preprint self- } \\
\text { archived. May negotiate. May ask for } \\
\text { it to be removed. }\end{array}$ & No problem \\
\hline$(7)$ & $\begin{array}{l}\text { No problem } \\
\text { May not publish if preprint self- } \\
\text { archived. May negotiate. May ask for } \\
\text { it to be removed. }\end{array}$ & $\begin{array}{l}\text { May refuse to publish if post-print has } \\
\text { been made available. May negotiate. } \\
\text { May ask for it to be removed. }\end{array}$ \\
\hline$(8)$
\end{tabular}

Figure 15 Self-archiving options for academic authors

\subsection{Publishers}

Proponents of open-access have iterated that they are not 'anti-publishers'. In fact they are neutral about their role. However, a certain amount of apprehension amongst publishers about a potentially dramatic shift in their market place is understandable. The ALPSP survey has shown that academics want to be able to self-archive whilst also valuing the certification that publishing in a refereed journal 'brand' gives them. These two aspects of scholarly communication could be separated out and labelled 'communication' (via self-archiving) and 'publication' (via formal journal publishing), or 'first publication' and 'definitive publication' as proposed by the Defining and certifying electronic publication (2000) report to the International Association of STM Publishers. Open-access supporters see the two existing side by side, thus the ideal future scenario is that publishers support the former (preferably by requiring only a non-exclusive licence to publish), whilst still being rewarded for the latter.

To support self-archiving, publishers will either need to relinquish copyright ownership entirely and obtain only a non-exclusive licence to publish, or obtain copyright and licence the author or institution the right to self-archive. As copyright law has chosen to confer rights to the creators of intellectual property (or their employer), and not (primarily) to those that publish it, it would seem logical for those creators to retain those rights. However, for journal publishing to remain viable, what is required is a means of valuing and protecting the services and 'added-value', that journal publishers provide.

\subsection{Conclusions}


One thing that all parties (academics, universities, publishers and proponents of open access) would agree on, is that the uptake of author self-archiving has been very slow to date. However, it is still very much at the fore of current thinking, and the investment of $£ 900,000$ by the UK JISC (2003) into it's FAIR (Focus on Access to Institutional Resources) programme, continues to raise the profile of open access within UK HE. This paper has demonstrated how the success of open access will be affected by a number of different copyright ownership models, and has recommended various approaches to copyright management that will enable that success. Effecting change in this area does not promise to be easy. However, as the Zwolle conferences have shown (Anon., 2003), constructive dialogue and imaginative thinking by all parties should provide a way forward.

\subsection{Future research}

Future studies in this series will address the following rights issues relating to selfarchiving:

\section{Study 2: How academics want to protect their open-access research papers}

This study will draw on section B of the academic author survey where respondents were asked to indicate the permissions, restrictions and conditions under which they would want to protect their own self-archived research papers.

\section{Study 3: - How academics expect to use open-access research papers}

This study will draw on section $\mathrm{C}$ of the academic author survey where respondents were asked to indicate the permissions, restrictions and conditions under which they would expect to use others' papers.

\section{Study 4: Journal copyright transfer agreement analysis}

This study will report in full on our analysis of 80 journal CTAs. It will consider when rights are assigned; what rights are retained; author and publisher warranties; and what authors are permitted to do with their research papers once copyright has been assigned.

\section{Study 5: IPR issues for OAI Data and Service Providers}

This study will consider the rights issues for Data and Service Providers in the context of the Open Archives Initiative. In particular it will focus on the rights status of metadata as opposed to the full-text documents.

\section{Study 6: Rights metadata for open-archiving}

A report on the rights metadata solution proposed by the RoMEO project which will afford protection to research papers made freely available on the web. It will also consider a means of protecting the rights status of metadata itself.

\section{Acknowledgement}

The authors gratefully acknowledge the Joint Information Systems Committee for funding the RoMEO Project. 


\section{References}

AAU/ARL (1994). Report of the AAU Task Force on Intellectual Property Rights in an Electronic Environment. Washington DC, Association of American Universities. URL: http://arl.cni.org/aau/IPTOC.html.

ALPSP (Association of Learned and Professional Society Publishers) (1999). What authors want :the ALPSP research study on the motivations and concerns of contributors to learned journals. London, Association of Learned and Professional Society Publishers.

ALPSP (Association of Learned and Professional Society Publishers) (2000) Model Grant of Licence. URL: http://www.alpsp.org/grantli.pdf

ALPSP (Association of Learned and Professional Society Publishers) (2002) Association of Learned and Professional Society Publishing. URL: http://www.alpsp.org/

Angell, M., and Kassirer, J.P. (1991) "The Ingelfinger rule revisited." New England Journal of Medicine, 325(19), 1371-1373. URL:

http://www.nejm.org/hfa/ingelfinger.asp

Anon. (2003). The Zwolle approach: balancing stakeholders' interests in scholarshipfriendly copyright practices. Report of working conference on Copyright and Universities: from principles to practices, Zwolle, 6 and 7 December 2002. URL: http://www.surf.nl/copyright/zwolle/2002dec/index.php.

ARL (Association of Research Libraries) (2000). Principles for emerging systems of scholarly publishing. Association of Research Libraries:

http://www.arl.org/scomm/tempe.html.

ArXiv (2003). URL: http://ArXiv.org/

Association for University Research and Industry Links (2002). Managing intellectual property: a guide to strategic decision-making in universities. London, Association for University Research and Industry Links; Universities UK; Patent Office. URL: http://www.patent.gov.uk/about/notices/manip/

Bammel, Jens. (1999). "The publisher-author relationship: principles of good practice in scholarly journal publishing." Learned Publishing 12(2). 75-78.

Baty, P. (2002). Cambridge row over rights plan. Times Higher Education Supplement (1549), 6.

Bennett, S. (1998). Position Paper on Yale University Copyright Policy Prepared for the Cooperative Research Committee. Connecticut, Yale University: URL: http://www.library.yale.edu/\%7Ellicense/bennett.html.

Crews, Kenneth. (1993) Copyright, fair use, and the challenge for universities: promoting the progress of Higher Education, Chicago, University of Chicago Press. 
Crow, R. (2002). The case for institutional repositories: a SPARC position paper.

Washington DC, The Scholarly Publishing and Academic Resources Coalition. URL: http://www.arl.org/sparc/IR/ir.html.

Davies, Pam (2002) Personal correspondents to Elizabeth Gadd, 10 September 2002.

"Defining and certifying electronic publication in science. A proposal to the International Association of STM Publishers." (2000) Learned Publishing 13(4), 251258.

Department for Education and Skills (2003). The future of Higher Education Cm.5735. London, The Stationery Office.

Department for Trade and Industry (2000). Excellence and opportunity - science and innovation policy for the 21st century. $\mathrm{Cm} 4814$. London, The Stationery Office. URL: http://www.ost.gov.uk/enterprise/dtiwhite/index.html

Department for Trade and Industry (2001). Opportunity for all in a world of change: White Paper on enterprise, skills and innovation, DTI and DfEE. London, The Stationery Office. http://www.dti.gov.uk/opportunityforall/.

Emerald Literati Club. (2003) URL: http://www.literaticlub.co.uk/

Evans, R. J. (2002). "Why I ...believe Cambridge's IPR Proposals Threaten Academic Freedom”. Times Higher Educational Supplement (1562),16.

Gadd, E. A. (2002). Clearing the way: copyright clearance in UK libraries. LISU Occasional Paper No. 31. Loughborough, LISU: 109pp.

Great Britain. (1977). Patents Act 1977, Ch. 39 Elizabeth II. London: HSMO

Great Britain. (1988). Copyright, designs and patents Act 1988, Ch. 11 Elizabeth II. London : HMSO

Guédon, J.-C. (2001). In Oldenburg's Long Shadow: Librarians, Research Scientists, Publishers, and the Control of Scientific Publishing. Creating the Digital Future: Association of Research Libraries: Proceedings of the 138th Annual Meeting, Toronto, Ontario, URL: http://www.arl.org/arl/proceedings/138/guedon.html.

Harnad, S. (2001). For Whom the Gate Tolls? How and Why to Free the Refereed Research Literature Online Through Author/Institution Self-Archiving, Now. URL: http://cogprints.soton.ac.uk/documents/disk0/00/00/16/39/index.html.

Harper, G. (2001). Managing the Risk of Copyright Infringement Liability, Texas, University of Texas System. URL:

http://www.utsystem.edu/ogc/intellectualproperty/riskmgt.htm.

HEFCE (Higher Education Funding Council for England). (2003). E-University. URL: http://www.hefce.ac.uk/Partners/euniv/ 
Hunt, C. (2002). Archive User Survey. Electronics and Computer Science Department. Southampton, Southampton University. URL:

http://www.eprints.org/results/.

ICMJE (International Committee of Medical Journal Editors). (2001) Uniform

requirements for manuscripts submitted to biomedical journals. URL:

http://www.icmje.org/

Jaffe, S. (2002). "The next Research Assessment Exercise will probably include citation analysis." The Scientist 16(22): 54.

JISC (Joint Information Systems Committee). (2003) Focus on Access to Institutional Resources programme. URL:

http://www.jisc.ac.uk/index.cfm?name=programme fair

JISC Scholarly Communications Group (2002). Final Report from the JISC Scholarly Communications Group (SCG) to the Research Support Libraries Group (RSLG).

London, Joint Information Systems Committee. URL:

http://www.jisc.ac.uk/jcie/scg/rslg.pdf.

Kulkarni, S. R. (1995). "All Professors Create Equally: Why Faculty Should Have Complete Control Over the Intellectual Property Rights in Their Creations." Hastings Law JournaI 47(November 1995): 22-256.

Law, D. G., R.L. Weedon, and M.R.Sheen (2000). "Universities and article copyright." Learned Publishing 13(3): 141-150.

Lawrence, S. (2001). "Online or invisible?" Nature 411(6837): 521 URL: http://www.neci.nec.com/ lawrence/papers/online-nature01/.

Long, Maurice. (1998). “Authors and their rights.” Learned Publishing 11(1), 3-4.

Morris, Sally. (2000) Guest Editorial. "Authors and Copyright”. Learned Publishing. 13(2), 75-76.

Morris, Sally. (2003) Open Access: what does it mean for STI distribution? [Unpublished conference presentation] Open Access to Scientific and Technical Information: State of the Art and Future Trends, Paris, 23-24 January 2003. URL [Web cast]: http://webcast.in2p3.fr/openaccess/morris.ram

Mossink, W. (1999). Copyright Policy for universities: A proposal from the SURF Foundation for a joint copyright policy for the Dutch universities. The Netherlands, SURF Foundation /IWI and Open Universiteit Nederland. URL: http://www.surf.nl/en/download/iwi\%20auteursrechten\%20UK\%20def.pdf.

NSF (National Science Foundation) Division of Science Resources Statistics. Science and Engineering Indicators-2002. Arlington, VA. URL: http://www.nsf.gov/sbe/srs/seind02/intro/intro.htm 
Office of Fair Trading (2002). The market for scientific, technical and medical journals: A statement by the OFT. London, Office of Fair Trading: 27 URL: http://www.oft.gov.uk/News/Press+releases/2002/PN+55-

$02+$ Can + the + scientific + journals + market + work + better $\% 3 \mathrm{f} . h t m$

Oliver, Rhonda. "Copyright assignment - some practical considerations." Learned Publishing 11(1), 4-5

Oppenheim, C. (1996). Copyright in HEIs: a discussion paper. Strathclyde, Department of Information Science. URL:

http://www.jisc.ac.uk/pub/copyright/charles1.htm

Oppenheim, C. (2001). "Is copyright strangling higher education?" UKOLUG Newsletter 12(5): 26-29.

Page, G., Robert Campbell and Jack Meadows. (1997). Journal Publishing. Cambridge, Cambridge University Press.

Picciotto, Sol (2002) Personal correspondence to Elizabeth Gadd, 4 September 2002.

RoMEO Project (2003). URL:

http://www.lboro.ac.uk/departments/ls/disresearch/romeo/index.html.

Rose, Mark. (1993) Authors and owners: the invention of copyright. Cambridge, Mass, Harvard University Press.

Schalkwyk, F., van (1998). "Beyond copyright: reconsidering the author/publisher/reader relationship." Logos 9(4): 207-218.

Society for Scholarly Publishing. (2002) URL: http://www.sspnet.org/

Suber, P. (2003). "Removing the barriers to research: an introduction to open access for Librarians." College and Research Libraries News 64, 92-94, 113. URL: http://www.earlham.edu/ p peters/writing/acrl.htm

Swan, A. (2002). Authors and electronic publishing: the ALPSP research study on authors' and readers' views of electronic research communication. West Sussex, ALPSP: 83pp.

Ulrichs Periodicals Directory Database (2003). Available online via Bowker.

Universities UK/Standing Conference of Principals (2002). Report of the HEFCE, Universities UK and Standing Conference of Principals (SCOP) Working Group on intellectual property rights (IPRs) in e-learning programmes. London, Higher Education Funding Councils, Universities UK, Standing Conference of Principals. [IN PRESS - WILL SUPPLY FINAL REFERENCE AT PROOF STAGE]

US Copyright Office (2001). Copyright Law of the United States of America and related laws contained in title 17 of the United States Code. Washington, D.C., 
Library of Congress: US Copyright Office. URL:

http://www.copyright.gov/title17/circ92.pdf.

Weedon, R. (2000). Policy approaches to copyright in HEIs: a study for the JISC Committee for Awareness, Liaison and Training (JCALT). Glasgow, The Centre for Educational Systems.

Willinsky, J. (2002). "Copyright Contradictions in Scholarly Publishing." First Monday 7(11). URL: http://firstmonday.org/issues/issue7 11/willinsky/.

Zwolle Principles. (2002). URL:

http://www.surf.nl/copyright/keyissues/scholarlycommunication/principles.php\#Princ iples

\section{Notes}

${ }^{1}$ See the list provided by Project RoMEO at: http://www.lboro.ac.uk/departments/ls/disresearch/romeo/index.html

${ }^{2}$ This is due to the so-called Ingelfinger rule which asks authors to warrant that a work has not been previously published, and considers self-archiving to be prior publication. (See Angell \& Kassirer (1991))This is discussed further in RoMEO Studies 3 on the full journal CTA analysis. 